\title{
Dukungan Pasangan dalam Menyelesaikan Perkuliahan
}

\author{
Dedek Nafita Sari ${ }^{1}$, Muhammad Nasir ${ }^{2}$, Dedy Surya ${ }^{3}$. \\ 1.3Prodi Bimbingan dan Konseling Islam, IAIN Langsa dan ${ }^{2}$ Hukum Keluarga Islam, IAIN Langsa \\ 1 dedek21091997@gmail.com, ${ }^{2}$ hilwa.umam@gmail.com, ${ }^{3}$ dedysurya@iainlangsa.ac.id
}

$\begin{array}{ccc}\text { First received: } & \text { Revised: } & \text { Final Accepted: } \\ \text { 01 January 2019 } & \text { 02 February 2019 } & \text { 04 March 2019 }\end{array}$

\begin{abstract}
Getting married is human nature and is a human effort to manifest themselves into perfect beings. Married attracts new problems, especially for students who are trying to get an education. This research aims to support the problems of young couples in completing their lectures. This qualitative research uses Bart Smet's (1994) social support theory. This research is located in the Faculty of Usuluddin Adab and Da'wah, lain Langsa with a subject of 3 female students. Data collected through interview techniques are then analyzed with domain analysis to get a general and complete picture of the phenomenon. The results showed that the main causes of inhibition of lectures for students who had received academic problems were: repeating courses, no thesis titles and economic problems such as: no money when paying tuition fees. Social support provided by couples is support in the form of emotional support, support instruments, support support and appreciation support.

Keywords: Supporting Couples, Academic Problems, Economic Problems
\end{abstract}

\begin{abstract}
Abstrak
Menikah adalah fitrah manusia dan merupakan upaya manusia untuk mewujudkan diri menjadi makhluk yang sempurna. Menikah menimbulkan problematika yang baru, terutama bagi mahasiswa yang menempuh jenjang pendidikan. Penelitian ini bertujuan untuk menompang problematika pasangan muda dalam menyelesaikan perkuliahannya. Penelitian kualitatif ini mengunakan teori dukungan sosial Bart Smet (1994). Penelitian ini berlokasi di Fakultas Ushuluddin Adab dan Dakwah, lain Langsa dengan Subjek 3 orang Mahasiswi. Data yang dikumpulkan melalui teknik wawancara kemudian di analisis dengan analisis domain untuk mendapatkan gambaran umum serta menyeluruh dari fenomena tersebut. Hasil penelitian menunjukan bahwa penyebab utama penghambat penyelesaian perkuliahan mahasiswa yang telah menikah adalah problematika akademik seperti: mengulang mata kuliah, tidak ada judul skripsi dan problematika ekonomi seperti : tidak ada uang saat pembayaran Uang kuliah. Dukungan sosial yang diberikan oleh pasangan adalah dukungan dalam bentuk dukungan emosional, dukungan instrument, dukungan informatif dan dukungan penghargaan.
\end{abstract}

Kata Kunci : Dukungan Pasangan, Problematika Akademik, Problematika Ekonomi

\section{PENDAHULUAN}

Kesadaran tentang pentingnya
pendidikan yang dapat memberikan
harapan dan kemungkinan yang lebih baik
di masa mendatang, hal ini telah
mendorong berbagai upaya dan perhatian
seluruh masyarakat terhadap
perkembangan dunia pendidikan.
Pendidikan salah satu upaya dalam
rangka meningkatkan kualitas hidup
manusia, pada intinya bertujuan untuk

memanusiakan manusia, mendewasakan, serta merubah perilaku dan meningkatkan kualitas menjadi lebih.

Kesuksesan mahasiswa dalam proses studinya pada hakekatnya merupakan suatu prestasi yang sangat diharapkan oleh semua pihak, bukan hanya mahasiswa itu sendiri melainkan juga oleh orang tua, dosen, teman dan perguruan tinggi tempat mahasiswa tersebut melaksanakan proses perkuliahan 
(Saputra, Yusuf \& Syahniah, 2013). Jika kita melihat dalam dunia pendidikan, hampir di setiap perguruan tinggi terdapat sejumlah mahasiswa yang telah menikah. Tetapi sejauh ini belum ada data yang pasti mengenai hal ini. Sebenarnya ini adalah fenomena yang patut kita telusuri, karena kita mengetahui bahwa antara pendidikan dan menikah adalah dua hal yang berbeda namun keduanya saling berpengaruh.

Menurut Horton dan Hunt,(1996) perkawinan tidak hanya mencakup hak dan kewajiban untuk melahirkan dan membesarkan anak, tetapi juga seperangkat kewajiban dan hak istimewa yang mempengaruhi banyak orang atau masyarakat. Arti sesungguhnya perkawinan adalah penerimaan status baru dengan sederetan hak dan kewajiban yang baru serta pengakuan akan status baru oleh orang lain.

Sebagaimana Firman Allah Swt dalam surat An-Nur:32 yang berbunyi:

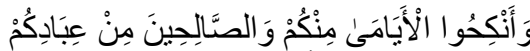

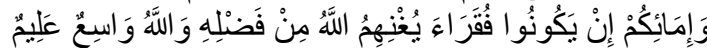
Artinya : Dan nikahkanlah orang-orang yang sendirian di antara kamu, dan orangorang yang layak (menikah) dari hamba-hamba sahayamu yang lelaki dan hamba-hamba sahayamu yang perempuan. Jika mereka miskin Allah akan memampukan mereka dengan kurnia-Nya. Dan Allah Maha luas (pemberian-Nya) lagi Maha mengetahui. (Q.S An-Nur 32)

Menurut Komariah (2004) Tujuan perkawinan adalah membentuk keluarga yang bahagia dan kekal. Untuk itu suami isteri saling membantu dan melengkapi, agar masing-masing dapat mengembangkan kepribadiannya membantu dan mencapai kesejahteraan spiritual dan materil.

Sebagaimana Firman Allah Swt dalam surat Ar-Rum: 21 yang berbunyi:

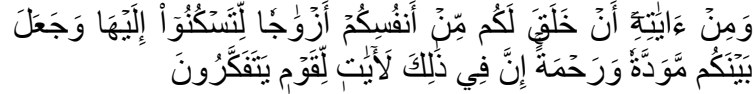

"Dan di antara tanda-tanda kekuasaanNya ialah Dia menciptakan untukmu isteriisteri dari jenismu sendiri, supaya kamu cenderung dan merasa tenteram kepadanya, dan dijadikan-Nya diantaramu rasa kasih dan sayang. Sesungguhnya pada yang demikian itu benar-benar terdapat tanda-tanda bagi kaum yang berfikir" (Q.S Ar-Rum: 21).

Fenomena yang terjadi di lapangan, menikah dengan seorang mahasiswa akan mengalami problematika yang baru, Pada hakikatnya pernikahan bukanlah hanya sebuah ikatan yang bertujuan untuk melegalkan hubungann bilogis saja, namun juga untuk membentuk sebuah keluarga yang menuntut pelaku pernikahan untuk mandiri dalam berpikir dan menyelesaikan masalah dalam pernikahan. Pasangan suami istri harus menjalani proses kehidupan yang berorientasi pada kesuksesan bersama pasangan, baik di dunia maupun akhirat (Ansori, 2015).

Pernikahan menjadi sebuah ikatan suci setelah terjadinya pengucapan akad dari pihak laki-laki kepada wali dari pihak perempuan. Sebagai umat muslim pernikahan merupakan sebuah ibadah yang sangat dianjurkan untuk ditunaikan. Dengan pernikahan maka akan terwujudnya suatu rumah tangga dan tercapainya tujuan dari suatu pernikahan yakni menjaga kesucian dari kedua belah pihak, tercapainya rahmat dan kasih sayang, serta ketenangan antar keduanya. Bekerjasama dalam melaksanakan berbagai kepentingan dunia dan agama serta dalam mendidik merawat anak-anaknya kelak. (al-Fauzan,2007)

Seseorang yang sudah menikah pasti memiliki status yang berbeda dengan 
sebelumnya. Jika sebelumnya berstatus single maka akan berubah menjadi status sudah menikah. Jika sebelumnya berstatus sebagai mahasiswi makan akan berubah menjadi anggota keluarga (suami/istri). Secara otomatis tugasdan tanggung jawab mereka juga bertambah, jika sebelumnya menikah mereka hanya memiliki tugas pokok belajar, tetapi setelah menikah tugas mereka bertambah dengan tugas keluarga yang berupa hak dan kewajiban suami istri, sebagaimana telah di atur dalam agama maupun UU pernikahan. (Baiyinah, Solina \& elsera, 2017).

Selain itu, banyak lagi perubahan yang harus mereka hadapi, seperti kebiasaan setiap hari bermain dan belajar dengan teman-teman sesuka hati, maka setelah menikah kebiasaan itu akan berganti kesibukan lain dengan suami atau istri mereka. Walaupun sebenarnya tidak semua begitu, karena ada suami yang tidak membatasi pergaulan istrinya yang masih kuliah.

Kurangnya dukungan pasangan diduga menjadi pemicu para mahasiswi terlambat menyelesaikan perkuliahan, idealnya, kuliah dapat terselesaikan Delapan Semester tapi, banyak yang lulus tidak sesuai dengan waktu yang sudah di tentukan.

Menurut sarwono dalam Deliyanty (2015), mengatakan bahwa dukungan adalah sebuah upaya yang diberikan kepada orang lain baik moril atau materil untuk memotivasi orang tersebut dalam melaksanakan tugasnya. Ada banyak sumber untuk mendapatkan dukungan. Menurut beach dkk dalam dorio, pasangan merupakan salah satu sumber dukungan yang paling dapat di percaya.

Gottlieb dalam Ainun Ni'mah (2009) mengatakan bahwa dukungan sosial terdiri dari informasi atau nasehat verbal atau non-verbal, bantuan nyata, atau tindakan yang diberikan oleh keakraban sosial atau didapat karena kehadiran mereka dan mempunyai manfaat emosional atau efek perilaku bagi pihak penerima

Beberapa mahasiswi di Institut Agama Islam Negeri Langsa telah melakukan pernikahan dimasa studi. Ada yang menikah di pertengahan dan di akhir perkuliahan, objek yang akan dikaji disini adalah mahasiswa prodi Bimbingan dan Konseling Islam.

Dalam peneitian ini terdapat dukungan sosial pasangan dan problematika dalam menyelesaikan perkuliahan .

\section{METODE}

Penelitian ini adalah penelitian kualitatif dengan pendekatan deskriptif. Bogdan dan Taylor mendefinisikan penelitian kualitatif sebagai penelitian yang menghasilkan data deskriftif berupa kata-kata tertulis atau lisan dari orangorang yang perilakunya diamati.(Maleong, 2002) Penelitian ini cenderung mengamati fenomena sosial yang kemudian dideskripsikan melalui kata-kata. (Bungin, 2009) Penelitian dilakukan di Fakultas Ushuluddin Adab dan Dakwah dengan Waktu penelitian 4 Bulan.

Sumber data yang dimaksud dalam penelitian ini adalah tempat data yang di peroleh dengan menggunakan metode tertentu baik berupa manusia, maupun dokumen-dokumen (Arikunto,2011) Sumber data penelitian yaitu data primer. Sumber data primer pada penelitian ini adalah informasi yang didapatkan dari lingkungan, orang tua dan pasangan yang sudah menikah. Dalam penelitian ini peneliti melakukan wawancara semi terstruktur adalah jenis wawancara yang sudah termasuk dalam kategori indephinterview,(Sugiyono,2017) dimana pelaksanaan lebih bebas dan lebih terbuka 
dalam melakukan wawancara untuk memperoleh data informasi tentang dukungan pasangan dalam menyelesaikan perkuliahan. Dalam proses wawancara ini yang menjadi sasaran peneliti adalah mahasiswi dan pasangannya.

Adapun proses analisis yang dilakukan oleh penulis dengan cara analisis domain yaitu memperoleh gambaran yang umum dan menyeluruh dari objek/ penelitian atau situasi sosial. Setelah itu ditemukan berbagai domain atau ketegori. Peneliti menetapkan domain tertantu sebagai pijakan untuk penelitian selanjutnya.(Sugiyono,2017)

\section{PEMBAHASAN}

\section{Gambaran Umum Subjek Penelitian}

Nama AA anak pertama dari pasangan MYD dan MH. AA anak pertama dari tiga bersaudara. Lahir di Tangkahan Durian, 27 Febuari 1997, ia sekolah di Sekolah Dasar (SD) Tangkahan Durian, lalu melanjutkan Sekolah di MTS Besitang, dan Sekolah Menengah Pertama (SMA) Tanjung Pura.

Setelah tamat dari Sekolah
Menengah Pertama (SMA) AA
melanjutkan perkuliahan di IAIN Langsa, setelah menempuh pendidikan di bangku kuliah sampai semester 6, ia menikah dengan pasangannya yang bernama SI. SI kelahiran Idi, 21 April 1992, usia pada itu AA berusia 21 tahun dan suaminya berusia 26 tahun. Menikah di KUA Tangkahan Durian 21 April 2018 . Setelah menikah ia di karuniai seorang Anak, saat ia melahirkan ia mengambil cuti di semester 9 , sebelumnya ia mahasiswa yang aktif dan belum pernah mengambil cuti sebelumnya hanya cuti melahirkan. Rencana ia akan melanjutkan perkuliahannya di semester 10 ini menginggat ia hanya tinggal skripsi saja, awalnya ia enggan melanjutkannya lagi tapi, dapat dukungan lebih dari suami sehingga ia berencana melanjutkan perkuliahan lagi.

Nama BB anak pertama dari pasangan $R$ dan Z . BB anak keempat dari lima bersaudara. Lahir di Aceh tamiang, 06 Mei 1996, ia sekolah di Sekolah Dasar (SD) Aceh Taming, lalu melanjutkan Sekolah di SMP Aceh Tamiang, dan Sekolah Menengah Pertama (SMA) Karang Baru.

Setelah tamat dari Sekolah Menengah Pertama (SMA) BB melanjutkan perkuliahan di IAIN Langsa, setelah menempuh pendidikan di bangku kuliah sampai semester 7, ia menikah dengan pasangannya yang bernama J. Sebelumnya ia mahasiswa yang aktif dan belum pernah mengambil cuti sebelumnya hanya cuti melahirkan. Rencana ia akan melanjutkan perkuliahannya di semester 10 ini menginggat ia hanya tinggal skripsi dan mengulang beberapa Mata Kuliah, awalnya ia enggan melanjutkannya lagi tapi, dapat dukungan lebih dari suami sehingga ia berencana melanjutkan perkuliahan lagi.

Nama CC anak dari pasangan MI dan N, CC anak pertama dari empat bersaudara. Lahir di telaga meuku sa, 1 desember 1992. Pernah sekolah di MI telaga meuku sa, MTS telaga meuku sa dan melanjutkan MAS sugaiyu. Setelah 4 tahun menganggur lalu melanjutkan kuliah di IAIN langsa. Sering berjalannya kuliah saya menikah di semester 7 dengan pasangan saya yang sekarang menjadi suami saya. Suami saya bernama suami $M$ lahir di bayeun, 25 juli 1986, perbedaan usia CC dan M 5 tahun, CC menikah pada usia 27 tahun dan M berusia 33 tahun. Perbedaan Usia yang lumayan jauh tidak menjadi masalah untuk mereka menikah dan akhirnya mereka menikah di tanggal 15 febuari 2019 dan saat ini CC sedang hamil, usia kandungan 7 bulan. CC tinggal di rumah orang tuanya. 


\section{Dukungan Sosial Pasangan}

Menurut Jacobson dalam

Nurmalasari, ( 2007) dukungan sosial adalah suatu bentuk tingkah laku yang menumbuhkan perasaan nyaman dan membuat individu percaya bahwa ia dihormati, dihargai, dicintai dan bahwa orang lain bersedia memberikan perhatian dan keamanan.

Menurut Apollo dan Cahyadi (2012), dukungan sosial adalah tindakan yang bersifat membantu yang melibatkan emosi, pemberian informasi, bantuan instrumen, dan penilaian positif pada individu dalam menghadapi permasalahannya.

Dari definisi diatas dapat disimpulkan bahwa dukungan sosial adalah segala sesuatu yang diterima individu dari orang terdekat baik berupa motivasi, tidakan dan perhatian. Dukungan sosial terdiri dari dukungan keluarga dan dukungan sosial pasangan yaitu:

Menurut Fridman (2002), dukungan keluarga adalah sikap tindakan penerimaan keluarga terhadap anggota keluarganya, berupa dukungan informasional, dukungan penilaian dan dukungan emosional. Jadi dukungan keluarga adalah suatu bentuk hubungan interpersonal yang meliputi sikap, tindakan dan penerimaan terhadap anggota.

Menurut sarafino dalam smeat (1994) dukungan pasangan yang diberikan dapat diwujudkan dalam beberapa bentuk antara lain dukungan emosi yaitu, perkataan yang baik dan lembut. Pasangan yang berkeluarga memberikan bujukan atau rayuan kepada pasangannya agar secepatnya menyelesaikan perkuliahan.

Dukungan suami dapat diartikan sebagai bantuan atau sokongan yangditerima individu lain sebagai orang terdekat antara anggota keluarga inti. Beberapa pendapat mengatakan bahwa dukungan sosial terutam. (Nursalam \& Ninuk, 2007).

\section{Problematika dalam Penyelesaian Perkuliahan Bagi Mahasiswi Yang Sudah Menikah.}

Kuliah merupakan proses pembelajaran tingkat lanjut dibidang formal dimana didalam perkuliahan terdapat pilihan jurusan. Melanjutkan pendidikan ke perguruan tinggi atau kuliah tentunya adalah idaman setiap orang.

Menurut siswoyo, (siswoyo, 2007) mahasiswa dapat didefinisikan sebagai individu yang sedang menuntut ilmu ditingkat perguruan tinggi, baik negeri maupun swasta atau lembaga lain yang setingkat dengan perguuran tinggi. Mahasiswa dinilai memiliki tingkat intelektualitas yang tinggi, kecerdasan dalam berpikir dan kerencanaan dalam bertindak.

Faktor pendukung dalam menyelesaikan perkuliahan. yakni dukungan, dimana dukungan dalam menghadapi sebuah hambatan dalam menyelesaikan perkulaiahn diperlukan sumber dukungan, sumber dukungan tersebut dapat berasal dari luar dan dalam individu. Dukungan yang berasal dari dalam individu bisa berupa penemuan tujuan tertentu, merasa ingin tahu, dan merasa bertanggung jawab atas penyelesaian perkuliahan. Sedangkan dukungan dari luar adalah mendapatkan penghargaan dan mendapatkan pujian.

Faktor penghambat dalam menyelesaikan perkuliahan dalam menyelesaikan perkuliahan terdiri dari faktor internal dan eksternal yaitu: Faktor internal yang mempengaruhi mahasiswa dalam menyekesaikan perkuliahan pada 
mahasiswa bimbingan dan konseling islam. Faktor jasmani, seperti : kondisi tubuh. Dan faktor psikologis, seperti : kesulitan diri, minder, dan kurang percaya diri. Faktor kelelahan, seperti : terganggu dalam manajemen wakgtu, merasa malas dalam melakukan tugas kuliah.

Menikah dimasa kuliah sebagian besar akan menjadi problematika dalam menyelesaikan perkuliahan. Beberapa problematika yang dialami subjek penelitian penulis dapat diidentifikasi dengan pendekatan problematika akademik dan problematika ekonomi. Masing-masing subjek memiliki karakteristik dan problematika masingmasing dalam beradaptasi dengan kehidupan keluarga dan kehidupan kampus.

\section{Problematika Akademik}

Mahasiswi yang menikah terkait akan problematika akademik, karena hasil wawancara menyimpulkan bagi mahasiswi yang sudah menikah sulit menyelesaikan perkuliahan. Dikarenakan ketika suami pergi kerja maka otomatis ia membagi waktu antara anak dan kuliah. Tanggung jawab mahasiswi dalam menyelesaikan perkuliahan dengan perkembangan anaknya itu sama-sama penting bagi yang sudah memiliki anak. Itu salah satu penyebab merekabelum ada waktu unutuk menyelesaikan perkuliahan. Subjek yang mengalami problematika akademik yaitu AA, BB dan CC.

Keputusan untuk menikah bagi mahasiswa merupakan keputusan yang harus dipikirkan dengan matang. Karena setiap keputusan yang diambil memiliki konsekuensi tertentu. Jika mahasiswa tersebut telah mengambil keputusan untuk menikah, tentu ia harus dapat menyeimbangkan antara kehidupan rumah tangga dan tugas kuliahnya, karena biasanya jika seseorang sudah menikah maka waktunya akan lebih banyak tersita untuk menjalankan kehidupan rumah tangganya. Oleh karena itu banyak hal yang harus dipertimbangkan sebelum mengambil keputusan untuk menikah seperti harus memiliki pemahaman dan penyesuaian diri, baik dengan kehadiran pasangan, keluarga baru, anak, tanggungjawab serta konflik dalam pernikahan sebelum mereka memutuskan untuk menikah.

Mengenai menikah saat kuliah, $\mathrm{M}$. Fauzil Adhim dalam bukunya Indahnya Pernikahan Dini mengatakan bahwa menikah tidak akan mengganggu kemampuan dalam menyerap materi perkuliahan jika dalam pernikahan tersebut mencapai kesejahteraan jiwa sesudah menikah. (Adhim, Zimbardo, dan Gerrig, 2007) Tetapi ketika dalam pernikahan tersebut tidak bisa mencapai kesejaheraan jiwa. maka pernikahan tersebut bisa mengganggu studi. Bahkan pernikahan yang dilaksanakan akan cenderung berakhir dengan perceraian. Hal ini disebabkan karena kesiapan mental mereka dalam membangun sebuah keluarga belum matang.(Irfan, 2007)

Tentang pernikahan yang berlangsung saat masih studi sebagaimana dikutip Mohammad Fauzil Adhim bahwa Hoffman juga berkata:

“Sebagian mahasiswi sempat
terganggu kuliahnya, tetapi
sebagian besar tidak mengalami
hambatan apa-apa dalam
menyelesaikan studinya di
perguruan tinggi. Masa yang paling
banyak menimbulkan hambatan
kuliah adalah ketika memiliki anak
pertama. Ini karena mereka harus
melakukan penyesuaian diri 
dengan peran baru sebagai orang tua, kebingungan bagaimana harus menghadapi perilaku bayi, serta perubahan fisik yang terasa mendadak". (Adhim, 2007)

Walaupun sebagian orang dapat terganggu dalam perkuliahannya ketika dirinya baru pertama kali memiliki anak, tetapi pernikahannya dapat membuat kondisi psikis lebih tenang. Ini dapat membantu kemampuan otak lebih efektif sehingga dapat menelaah materi studi dengan lebih baik. dalam keadaan ini mendorong untuk memiliki kompetensi yang lebih tinggi. Hal yang terpenting bagi seseorang yang sudah menikah dan masih aktif dalam perkuliahan adalah bagaimana caranya mengatur waktu untuk membagi kewajiban antara keluarga dan kuliah atau belajar. Karena apabila seseorang tidak pandai membagi waktu, bisa mengakibatkan salah satu kewajibannya terganggu. Dalam pengaturan waktu tersebut seseorang dituntut untuk berfikir lebih ekstra karena mempunyai beban tanggung jawab yang harus dipenuhi.(Jamil, 2016)

\section{Problematika Ekonomi}

Faktor ekonomi sangat mempengaruhi keberhasilan akademik mahasiswa maupun pelajar. Dalam kehidupan keseharian mahasiswa yang telah menikah tentu memiliki tanggung jawab ganda, selain menjadi istri atau ibu, mahasiswa juga mempunyai kewajiban menyelesaikan tugas kuliah yang juga membutuhkan dana. Bagi mahasiswa yang tidak bisa mengatur keuangan untuk kebutuhan pribadi dan menjadikan dampak buruk.(Syah \& Muhibbin, 2010)

Mahasiswi yang menikah terkait akan problematika ekonomi, karena hasil wawancara menyimpulkan bagi mahasiswi yang sudah menikah sulit menyelesaikan perkuliahan. Dari ketiga subjek, mahasiswi yang menikah terkait akan problematika ekonomi, tidak semua mengalaminya, tetapi hal ini hanya satu banding dua yaitu CC. Karena CC walaupun baru menikah dan sedang hamil ia memiliki kebutuhan yang sama seperti mereka yang memiliki anak, hanya saja CC kurang beruntung dari pada AA dan BB. Sehingga CC tidak mampu melanjutkan kuliahnya dikarenakan pada saat itu ia tidak membayar uang kuliah di karenakan suaminya pada saat itu tidak memiliki uang.

Masalah keuangan adanya tidak seimbangan antara kebutuhan manusia yang tidak terbatas sehingga menjadi pemicu kekurangan ekonomi sehingga tidak mampu menyelesaikan perkuliahan. Masalah keuangan bagi mahasiswa memang bukan hal yang baru. Meskipun banyak bantuan dari pemerintah untuk mendapatkan bantuan keuangan, para mahasiswi ini sebanarnya bisa menemukan beragam ide kreatif untuk mendapatkan uang . karena ia sudah menikah menjadi kendala baru, dimana ia harus mengatur keuangan dalam rumah tangga dan mengatur uang kuliah, sehingga ia korbankan kebutuhan kuliah untuk mencukupi kebutuhan rumah tangganya.

Jadi menurut pengamatan peneliti bahwa problematika yang terjadi dalam penyelesaian kuliah itu sebagian besar problematika akademik yang terjadi saat ini pada mahasiswi yang sudah menikah. Tidak menutup kemungkinan problematika ekonomi juga menjadi pengaruh dalam menyelesaikan perkuliahan tapi tidak seberapa besar pengaruh problematika ekonomi dibandingkan dengan problematika akademik.

\section{SIMPULAN}

Bedasarkan hasil penelitian pada bab sebelumnya, maka berikut ini peneliti akan 
memaparkan kesimpulan dari hasil penelitian serta saran yang diberikan sehubungan dengan masalah yang telah diteliti sebagai berikut:

Problematika dalam penyelesaian perkuliahan bagi mahasiswa yang sudah menikah. Ada dua problematika yang ada di dalam diri mahasiswi yaitu, problematika akademik dan problematika ekonomi. Hasil dari wawancara peneliti dengan narasumber bahwa sebagian besar kendala mereka ada di problematika akademik. Mereka belum ada judul skripsi dan masih ada mata kuliah yang mengulang terus mereka yang sudah menikah dan memiliki anak, mereka enggan untuk melanjutkan perkuliahan, dikarenakan mereka harus mengurus pekerjaan rumah tangga, suami dan anak. Problematika ekonomi, ekonomi bisa menjadi pemicu mahasiswa tidak bisa melanjutkan perkuliahan, tapi menurut hasil wawancara problematika ekonomi tidak seberapa berpengaruh, lebih besar pengaruh problematika akademik dibandingkan dengan problematika ekonomi. Dukungan sosial pasangan dalam menyelesaikan perkuliahan. Setiap individu memiliki dukungan yang berbeda-beda dari pasangannya sebagaimana mestinya. Dukungan yang narasumber dapatkan itu dalam bentuk berbeda-beda tapi tetap tujuannya sama. Dukungan yang diberikan yaitu dukungan emosional, dukungan instrument, dukungan informatif dan dukungan penghargaan.

\section{DAFTAR PUSTAKA}

Al-Fauzan, A. A. (2007). Fikih Sosial: Tuntutan \& etika hidup bermasyarakat. Jakarta: Qisthi Press.
Saputra, N. A., Yusuf, A. M., \& Syahniar, (2013). Kinerja Dosen Penasehat Akademik dan Hubungannya dengan Masalah Akademik Mahasiswa dalam Perkuliahan. Jurnal Konseling Indonesia. 1 (3). https://doi.org/10.29210/110900.

Horton, P. B., \& Hunt, C. L. (1996). Sosiologi. Jilid I. Surabaya: Erlangga.

Ansori, A. A. (2015). "Dinamika Pernikahan Pada Mahasiswa S-1" Skripsi. Fakultas Psikologi Universitas Muhammadiyah: Surakarta.

Nurmalasari, Y., \& Putri, D. K. (2007). Hubungan Antara Dukungan Sosial Dengan Harga Diri Pada Penderita Pada Penyakit Lupus. Jurnal Fakultas Psikologi Universitas Gunadarma.

Nursalam., \& Ninuk, D. K. (2007) Asuhan Keperawatan Pada Pasien Terinfeksi HIV AIDS, Salemba Medika: Jakarta.

Maleong, L. J. (2002). Metodologi Penelitian Kualitatif. Bandung: Remaja Rosdakarya.

Bungin, B. M. (2009). Penelitian Kualitatif. Jakarta: Kencana Prenada Media Group.

Irfan, L. A. (2007) Seri Tuntunan Praktis Ibadah, Nikah. Yogyakarta: Pustaka Insani Madani.

Syah, M. (2010). Psikologi Belajar. Jakarta: PT. Rajagrafindo Persada.

Johnson, D. P. (1994) Teori Sosiologi Klasik dan Modern. Jakarta: Gramedia 